\title{
Pigeonpea Nutrition and Its Improvement
}

\author{
K. B. Saxena \\ R. V. Kumar \\ P. V. Rao
}

SUMMARY. Pigeonpea (Cajanus cajan [L.] Millsp.), known by several vernacular and trade names such as red gram, tuar, Angola pea, Congo pea, yellow dhal and oil dhal, is one of the major grain legume crops of the tropics and sub-tropics. It is a favorite crop of small holder dryland farmers because it can grow well under subsistence level of agriculture and provides nutritive food, fodder, and fuel wood. It also improves soil by fixing atmospheric nitrogen. India by far is the largest pigeonpea producer where it is consumed as decorticated split peas, popularly called as 'dhal.' In other countries, its consumption as whole dry seed and green vegetable is popular. Its foliage is used as fodder and milling by-products form an excellent feed for domestic animals. Pigeonpea seeds contain about $20-22 \%$ protein and appreciable amounts of essential amino acids and minerals. Dehulling and boiling treatments of seeds get rid of the most antinutritional factors such as tannins and enzyme inhibitors. Seed storage causes considerable losses in the quality of this legume. The seed protein of pigeonpea has been successfully enhanced by breeding from $20-22 \%$ to $28-30 \%$. Such lines also agronomically performed well and have acceptable seed size and color. The high-protein lines were found

K. B. Saxena is Senior Scientist (Breeding), R. V. Kumar is Scientific Officer (Breeding), and P. V. Rao is Scientific Officer (Biochemistry), International Crops Research Institute for the Semi-Arid Tropics, Patancheru 502 324, Andhra Pradesh, India.

[Haworth co-indexing entry nole]: "Pigeonpea Nutrition and Its Improvement." Saxena, K. B., R. V. Kunar, and P. V. Rao. Co-published sinultaneously in Jommal of Crop Production (Food Products Press, an imprint of The Haworih Press, Inc.) Vol. 5, No. 1/2 (\$9/10), 2002, pp. 227-260; and: Quality Improvemen in Field Crops (ed: A. S. Basta, and L. S. Rundhawa) Food Products Press, an imprint of The Haworth Press, Inc., 2002, pp. 227-260. Single or multiple copies of this article are available for a fee from The Haworth Document Delivery Service []-800-HAWORTH, 9:00 a.m. - 5:00 p.m. (EST). E-mail address: getinfo@ haworthpressinc.con].

(C) 2002 by The Haworth Press, Inc. All rights reserved. 
nutritionally superior to the cultivars because they would provide more quantities of utilizable protein and sulfur-containing amino acids. [Article copies available for a fee from The Haworth Document Delivery Service: 1-800-HAWORTH.E-mail address: <getinfo@haworthpressinc.com>Website: $<$ intp://www.HaworthPress.com> (C) 2002 by The Haworth Press, Inc. All rights reserved.]

KEYWORDS. Pigeonpea, Cajanus cajan (L.) Millsp., milling, thal, dehusking, cooking time, protein, breeding, amino acid, storage, fodder

\section{INTRODUCTION}

In Asia and Africa population growth is the prime development constraint. Recently, India has crossed the alarming 'one billion' population mark and it is catching up fast the most populous country China. Providing significant quantity of quality food to the growing population with limited resources is a big challenge. Due to increase in rural family size, where the population growth is over $2 \%$ per year, the land holdings are dividing by each passing generation leading to increased pressure on unit land and reduction in the capacity of farmers to produce sufficient quantity of nutritive food for their families. In producing food crops, such farmers try to keep a balance between cereals and legumes, besides aiming to obtain some fodder for cattle. However, their small holdings and lack of basic resources like water, fertilizer, and pesticides restrict the food production. In general, the food production from small holdings is short both in quantity and quality and under such circumstances, the expectant and nursing mothers and young children are the most vulnerable lots. Recently, a number of weaning and supplementary foods have come in market but due to high prices they remain a luxury of urban middle and upper classes. Since the animal protein is also out of their reach, the problem of malnutrition among poverty-ridden masses is achieving a serious dimension in the country. To meet this challenge, a concerted effort is needed to increase the production of protein-rich legume crops which can be grown under subsistence level of farming and no crop other than pigeonpea suits most because it is drought tolerant, need minimum inputs, and can produce reasonable amounts of food, fodder, and fuel wood. Pigeonpea seeds contain about $20-22 \%$ protein and reasonable amounts of essential amino acids. India is the largest producer of pigeonpea with annual production of three million tons harvested from about four million hectares. In the past 10 
years the area under pigeonpea is consistently increasing at the rate of $2 \%$ each per year (Ryan, 1997) but still its demand is out-scoring the supply and serious efforts are needed at every level to boost the production of this important legume. In India pigeonpea is predominantly consumed as dhal (decorticated dry split peas) but its whole seeds are also consumed in Africa and the Caribbean islands. In this chapter various aspects of pigeonpea nutrition are reviewed.

\section{GRAIN QUALITY OF PIGEONPEA}

Pal (1939) published perhaps the first review on the nutrition value of pulses in India. He compared different pulse crops for their digestibility coefficient, biological value, net protein value, and four essential amino acids. For biological value he judged pigeonpea as the best pulse crop and concluded that it makes the most nutritive food when eaten with rice. However, using an arbitrary scale for the overall nutrition value of the pulses, chickpea (Cicer arietinum) and black gram (Phaseolus mungo) were considered superior to pigeonpea. The nutritional value of food is determined by its chemical constituents and in pigeonpea a wide range is reported for these vital elements (Tripathi et al., 1975; Sharma et al., 1977; Narsimha and Desikachar, 1978; Manimekalai et al., 1979; Singh et al., 1984 a \& b). Besides inherent genotypic differences, such variation can be attributed to environment where the crop was grown, methods of sampling and analyses, and method and length of seed storage periods.

\section{Chemical Composition of Dry Seeds}

The distribution of some dietary nutrients in different parts of dry pigeonpea seed as reported by Faris and Singh (1990) is given in Table 1. Broadly, pigeonpea seed contains $85 \%$ cotyledons, $14 \%$ seed coat, and less than $1 \%$ embryo. Carbohydrates and proteins are major constituents of cotyledons, embryo, and seed coat. Quantitatively, the cotyledons $(66.7 \%)$ and seed coat $(58.7 \%)$ are rich in carbohydrates while protein $(49.6 \%)$ constitutes a major portion of embryo. Carbohydrates and fat are also present in significant quantities in embryo. About one-third of seed coat is made of fibers. The seed also contains amino acids, calcium, fiber, and iron. The contents of methionine and cystine, the sulfur-containing amino acids, range around $1 \%$ and they predominantly reside in cotyledons and embryo. Calcium is predominantly 
TABLE 1. Distribution of nutrients in mature pigeonpea seed.

\begin{tabular}{lcccc}
\hline Constituent & Whole seed & Cotyledons & Embryo & Seed coat \\
\hline Carbohydrates (\%) & 64.2 & 66.7 & 31.0 & 58.7 \\
Protein (\%) & 20.5 & 22.2 & 49.6 & 4.9 \\
Fat (\%) & 3.8 & 4.4 & 13.5 & 0.3 \\
Fiber (\%) & 5.0 & 0.4 & 1.4 & 31.9 \\
Ash (\%) & 4.2 & 4.2 & 6.0 & 3.5 \\
Lysine 1 & 6.8 & 7.1 & 7.0 & 3.9 \\
Threonine $^{1}$ & 3.8 & 4.3 & 4.7 & 2.5 \\
Methionine & 1.0 & 1.2 & 1.4 & 0.7 \\
Cystine $^{1}$ & 1.2 & 1.3 & 1.7 & - \\
Calcium $^{2}$ & 296 & 176 & 400 & 917 \\
Iron $^{2}$ & 6.7 & 6.1 & 13.0 & 9.5 \\
Thiamine $^{2}$ & 0.63 & 0.40 & - & - \\
Riboflavin $^{2}$ & 0.16 & 0.25 & - & - \\
Niacin $^{2}$ & 3.1 & 2.2 & - & - \\
\hline
\end{tabular}

Adapted from Faris and Singh (1990)

1: $9100^{-1}$ gprotein

2: $\mathrm{mg} 100^{-1} \mathrm{~g}$ dry matter

found in seed coat and embryo. Singh and Jambunathan (1982) studied distribution of major protein fractions in different components of pigeonpea seed and found that globulins constitute about $65 \%$ of total protein (Table 2). In comparison to other protein fractions globulin is inferior in sulfur-containing amino acids. Albumin, though in relatively small quantity, is rich in sulfur amino acids. The portion of prolamin in seed is low. According to Eggum and Beames (1983) pigeonpea is rated inferior to most other legumes as far as sulfur-containing amino acids is concerned but, unlike other legumes, the high protein content of pigeonpea seed is not tightly linked to its low methionine content (Singh and Eggum, 1984). Nigam and Giri (1961) observed that stachyose and verbascose constitute major component among sugars of pigeonpea. The pigeonpea starch has been found to be stable to heat up to $90^{\circ} \mathrm{C}$ (Modi and Kulkarni, 1976). 
TABLE 2. Major protein fractions (\%) in dry pigeonpea seed.

\begin{tabular}{lcccc}
\hline Component & Albumin & Globulin & Glutelin & Prolamin \\
\hline Whole seed & 10.2 & 59.9 & 17.4 & 3.0 \\
Embryo & 17.0 & 52.7 & 21.3 & 2.7 \\
Cotyledons & 11.4 & 64.5 & 18.2 & 3.5 \\
Seed coat & 2.6 & 26.3 & 32.8 & 4.2 \\
\hline
\end{tabular}

Adapled from Singh and Jambunathen (1982)

\section{Chemical Composition of Immature Seeds}

Physiologically mature green seeds of pigeonpea are consumed as vegetable in Dominican Republic, the Caribbean islands and some parts of India. In Dominican Republic $80 \%$ of the crop is exported as canned or frozen vegetable. Singh et al. (1977) compared vegetable pigeonpea (Figure 1) with that of pea (Pisum sativum) and found that pea seed had higher protein than pigeonpea but it was similar in crude fibre content. The trypsin inhibitors were more in pigeonpea when compared to pea but far less when compared with soybean. Nutritionally, green pigeonpea seed is considered superior to the dhal (Table 3). According to Faris et al. (1987) green pigeonpea seed is a rich source of iron, calcium, and magnesium when compared with its dhal. The green seed contains lower quantities of trypsin and amylase inhibitors and flatulence-causing sugars. The green seed cooks quickly and is also a better source of vitamin $A$. The protein and starch digestibility of green seed are higher than mature seed (Singh et al., 1984a). Singh et al. (1991) while studying chemical changes in the developing pigeonpea seeds, found that dry matter accumulation increased up to 28-32 days after flowering in different cultivars and recommended that for the best green pea yield, the crop should be harvested at nearly 30 days after flowering. The protein content and soluble sugars showed a gradual decrease with advancing maturation of seeds while its starch continued to increase. ICP 7035, a known vegetable type Indian pigeonpea landrace, was found to be more biochemically active in accumulating soluble sugars. This landrace was marginally low in calcium and magnesium at all the stages of seed development. The iron content of seeds also decreased as they approached maturity. In pigeonpea a range of pod color is found but it is not related to any quality parameter (Saxena et al., 1983). 
FIGURE 1. Vegetable pigeonpea (left) and green pea pods (right).
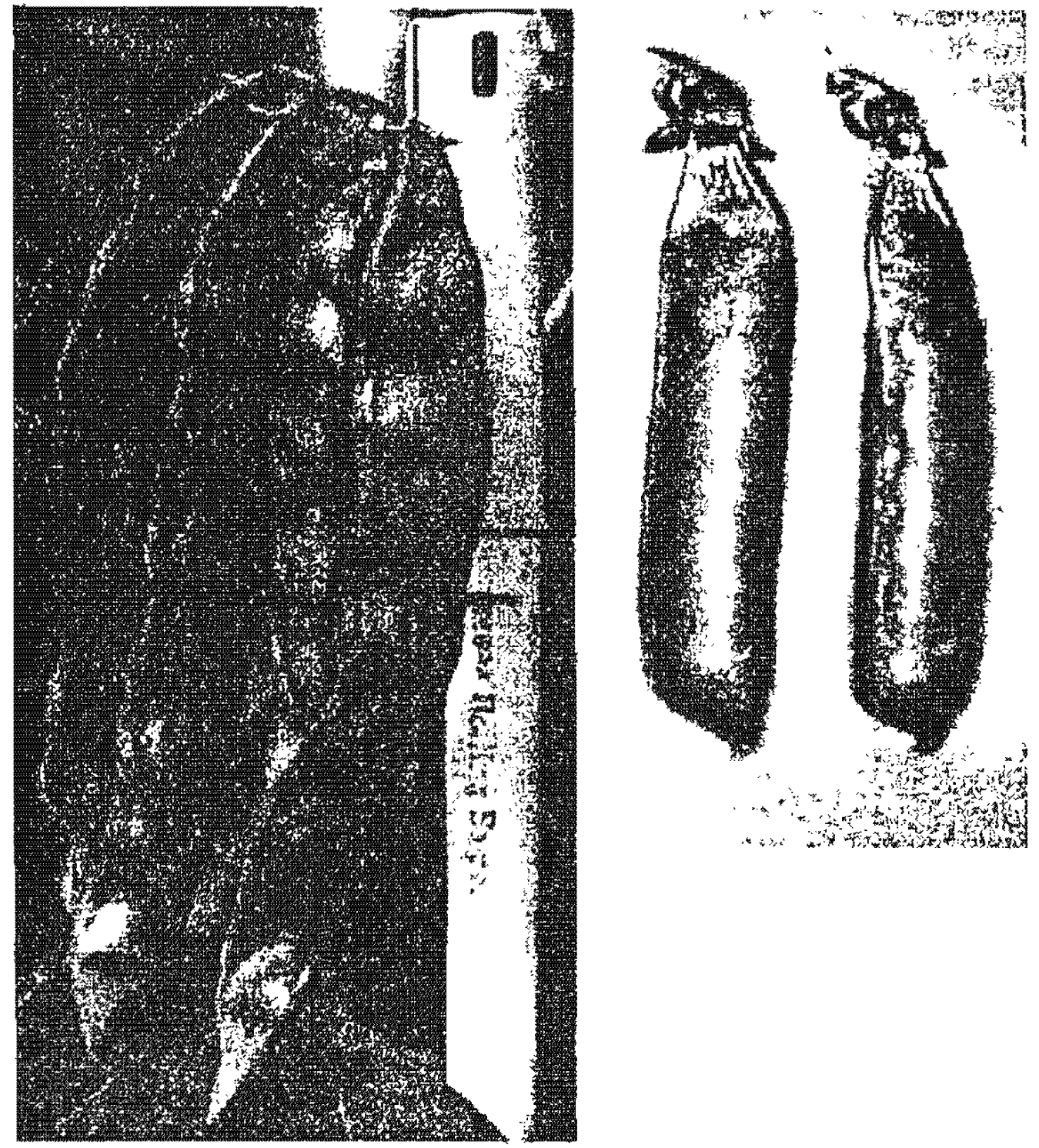

\section{Antinutritional Factors}

Like most legumes, pigeonpea also contains certain amounts of antinutritional factors. These include oligosaccharides (raffinose, stachyose, verbascose), polyphenols (phenols, tannins), phytolectins, and enzyme (trypsin, chymotrypsin, amylase) inhibitors. Singh (1988) studied a number of genotypes for quantifying important antinutritional factors and toxic substances present in pigeonpea seeds and found a large variation among genotypes for these traits (Table 4). Amylase and trypsin inhibitors and phenols were found in significant quantities. In addition, the flatulence causing sugars were also present in appreciable quantities. According to Kamath and Belavady (1980) pigeonpea seeds also contain certain unavailable carbohydrates which characteristically reduce the bioavailability of important nutrients. 
TABLE 3. Comparison of pigeonpea green seed and dhal for various nutritional consituents.

\begin{tabular}{lcc}
\hline Constituent & Dhal & Green seed \\
\hline Starch content (\%) & 57.6 & 48.4 \\
Protein (\%) & 24.6 & 21.0 \\
Protein digestibility (\%) & 60.5 & 66.8 \\
Trypsin inhibitor (unit mg ${ }^{-1}$ ) & 13.5 & 2.8 \\
Soluble sugars (\%) & 5.2 & 5.1 \\
Crude fiber (\%) & 1.2 & 8.2 \\
Fat (\%) & 1.6 & 2.3 \\
Calcium & & 94.6 \\
Magnesium $^{1}$ & 16.3 & 113.7 \\
Copper $^{1}$ & 78.9 & 1.4 \\
Iron $^{1}$ & 1.3 & 4.6 \\
Zinc $^{1}$ & 2.9 & 2.5 \\
\hline
\end{tabular}

Adapted from Faris et al. (1987)

$y=\mathrm{mg} 100 \mathrm{~g}^{-1}$ sample

TABLE 4. Genotypic variation for major antinutritional factors in pigeonpea.

\begin{tabular}{|c|c|c|}
\hline Factor & Genotypes & Range \\
\hline Total phenols $\left(\mathrm{mg} \mathrm{g}^{-1}\right)$ & 14 & $3.0-18.3$ \\
\hline Tannins $\left(\mathrm{mg} \mathrm{g}^{-1}\right)$ & 10 & $0.0 \cdot 0.2$ \\
\hline Trypsin inhibitor (units $\mathrm{mg}^{-1}$ ) & 9 & $8.1-12.1$ \\
\hline Chymotrypsin inhibitor (units $\mathrm{mg}^{-1}$ ) & 9 & $2.1-3.6$ \\
\hline Amylase inhibitor (units $\mathrm{g}^{-1}$ ) & 9 & $22.5-34.2$ \\
\hline Raffinose $\left(\mathrm{g} 100 \mathrm{~g}^{-1}\right)$ & 10 & $0.24-1.05$ \\
\hline Stachyose $\left(\mathrm{g} 100 \mathrm{~g}^{-1}\right)$ & 9 & $0.35 \cdot 0.86$ \\
\hline Stachyose + verbascose $\left(\mathrm{g} 100 \mathrm{~g}^{-1}\right)$ & 4 & $1.60-2.30$ \\
\hline
\end{tabular}


Godbole et al. (1994) reported the presence of protease inhibitor in seven-day old seed of variety TAT-10 while Ambekar et al. (1996) found that the inhibitors are either not synthesized or inactive up to 28 days of the seed development. No other plant part except seed recorded the presence of trypsin and chymotrypsin inhibitors (Mutimani and Paramjyothi, 1995). Since seed coat is rich in antinutritional factor it assumes greater importance where whole pigeonpea seeds are consumed. In many African, South American and Carribbean countries where dehulling facilities are not available and whole seed is consumed, predominantly white seeded cultivars are grown which contain relatively less quantity of polyphenols. Singh (1984) compared white, brown, and light brown seeded pigeonpea types for antinutritional factors (Table 5) and established strong relationship between seed coat color and antinutritional factors. He found three times greater quantity of polyphenols in the red seeded lines in comparison to the white seeded types. Similarly, the enzyme inhibition activity was much larger in the colored pigeonpea. In India almost entire pigeonpea production is converted into dhal. In this process the seed coat is removed and therefore the large amounts of tannins present in the colored pigeonpea pose no problem in its consumption. The amounts of polyphenols in dhal made

TABLE 5. Polyphenol contents and varietal differences in the enzyme-inhibitory property of pigeonpea polyphenols.

\begin{tabular}{|c|c|c|c|c|c|c|}
\hline \multirow[b]{2}{*}{ Gultivar } & \multirow[b]{2}{*}{ Testa color } & \multirow[b]{2}{*}{$\begin{array}{c}\text { Ployphenols } \\
\left(\mathrm{mg} \mathrm{g}^{-1} \text { sample }\right)\end{array}$} & \multicolumn{4}{|c|}{ Enzyme inhibition ${ }^{1}(\%)$} \\
\hline & & & Trypsin & $\begin{array}{l}\text { Chyco- } \\
\text { trypsin }\end{array}$ & $\begin{array}{c}\text { Human } \\
\text { saliva }\end{array}$ & $\begin{array}{c}\text { Hog } \\
\text { pancreas }\end{array}$ \\
\hline $\mathrm{Hy} 3 \mathrm{C}$ & White & 3.7 & 37.9 & 36.0 & 34.5 & 21.8 \\
\hline NP (WR) 15 & White & 6.0 & 40.5 & 38.6 & 32.7 & 19.7 \\
\hline C 11 & Light brown & 14.2 & 91.5 & 90.3 & 86.0 & 80.9 \\
\hline BDN 1 & Brown & 15.2 & 90.3 & 91.6 & 79.4 & 69.3 \\
\hline No. 148 & Brown & 14.9 & 88.0 & 85.9 & 75.8 & 68.5 \\
\hline Mean & & 10.8 & 69.7 & 68.5 & 61.7 & 52.0 \\
\hline SE & & \pm 0.2 & \pm 2.1 & \pm 1.7 & \pm 1.4 & \pm 1.3 \\
\hline
\end{tabular}

Based on assay using $200 \mathrm{mg}$ polyphenols for trypsin and chymoptrypsin, and $250 \mu \mathrm{g}$ polyphenols for amylase inhibitions.

Adapted from Singh (1984) 
either from red or white grain were found to be similar and ranged between 1.4 to $1.9 \mathrm{mg} \mathrm{g}^{-1}$ samples. Pichare and Kachole (1994) found no association between trypsin inhibitor activity and pod borer resistance in pigeonpea.

\section{HUMAN NUTRITION}

\section{Role of Pigeonpea in Rural Diets}

Methionine and cystine followed by tryptophan and threonine are the limiting essential amino acids in pigeonpea whereas lysine is the limiting amino acid in rice and wheat (Faris and Singh, 1990). A food combining cereals and pulses provide a balanced diet because they complement the amino acid profiles of each other. According to Hulse (1977), the mutual compensation is closest to the ideal value when the ratio by weight of cereals to legume is roughly 70:30. In southern and eastern Africa this ratio is $90: 10$ reflecting shortage of legume protein in the diet. Daniel et al. (1970) studied supplementation of cereal diets with various proportions of pigeonpea in rats and reported that supplementation of ration with pigeonpea significantly enhanced the nutritive value of the diet. Supplementation of rice diet with $8.5 \%$ and $16.7 \%$ pigeonpea $\mathrm{dhal}$ markedly improved the quality of diet (Table 6). Similarly, Kurien et al. (1971) demonstrated that a supplement of pigeonpea in maize diet significantly improved the quality of food.

TABLE 6. Effect of supplementary rice diets with varying levels of pigeonpea on the growth of young rats. ${ }^{1}$

\begin{tabular}{lcccc}
\hline Diet & $\begin{array}{c}\text { Protein } \\
(\%)\end{array}$ & $\begin{array}{c}\text { Gain in } \\
\text { mass }(\%)\end{array}$ & $\begin{array}{c}\text { Protein } \\
\text { intake }(\%)\end{array}$ & $\begin{array}{c}\text { Protein } \\
\text { efficiency } \\
\text { ratio }\end{array}$ \\
\hline Rice & 7.2 & 25.5 & 11.8 & 1.78 \\
Fice $+8.5 \%$ pigeonpea & 8.7 & 32.8 & 15.5 & 2.13 \\
Rice $+16.7 \%$ pigeonpea & 10.0 & 45.2 & 19.6 & 2.32 \\
Rice $+25.0 \%$ pigeonpea & 11.4 & 48.9 & 21.8 & 2.25 \\
\hline
\end{tabular}

1 Based on an experimental period of 4 weeks.

Adapted from Daniel el al. (1970) 
Bidinger and Nag (1981) conducted a village level study including 240 families of different resource groups, representing six villages located in three agro-climatic zones of India. They observed that pigeonpea was by far the most preferred pulse crop and its consumption patterns differed widely by age group, farm size, and the village. The consumption rate was found linear with small farmers consuming the least amount and the large farmers the most. The consumption of pigeonpea was also found to be related to the production. National Institute of $\mathrm{Nu}$ trition in India recommends cereal:pulse ratio of $3: 1$ for very young children, 5:1 for women, and 6:1 for men. In most cases in villages, these standards could not be met (Table 7). Bidinger and Nag (1981) also reported that $10 \%$ of the protein and $5 \%$ of energy in the village diets came from pigeonpea. The maximum lysine provided from the diet was $21.7 \%$. These values are low and reflect the low consumption of legumes. Prema and Kurup (1973) reported that pigeonpea contains cholesterol and phospholipid lowering effect. Globulin fraction of pigeonpea protein was found to have a significant hypolipidaemic action in rats fed with a high-fat and high-cholesterol diet. They reported marked reduction in the total and free cholesterol, phospholipids, and triglycerides contents in serum, liver, and aorta tissues of rat.

\section{Nutrition Losses in Dehulling}

In the Indian subcontinent pigeonpea is predominantly consumed in the form of dhal and conversion whole seed into dhal is a big industry in

TABLE 7. Relative cereal:pulse consumption by different age groups in six villages of central India.

\begin{tabular}{lccc}
\hline Village & \multicolumn{3}{c}{ Age group } \\
\cline { 2 - 4 } & 1 to 6 & 7 to 18 & Adults \\
\hline Aurepalle & $31: 1$ & $35: 1$ & $37: 1$ \\
Dokur & $23: 1$ & $31: 1$ & $42: 1$ \\
Shirapur & $15: 1$ & $14: 1$ & $17: 1$ \\
Kalman & $14: 1$ & $18: 1$ & $20: 1$ \\
Kanzara & $7: 1$ & $9: 1$ & $10: 1$ \\
Kinkheda & $9: 1$ & $10: 1$ & $10: 1$ \\
\hline
\end{tabular}

Adapted trom Bidinger and Nag (1981) 
the country. For commercial purposes, big machines are used for dehulling while in rural areas, dehulling is done by using traditional grinding stones called chakki or quern. Since the cotyledons of pigeonpea are attached tightly with seed coat by gums, the processing primarily involves loosening of husk followed by dehusking and splitting of the two cotyledons. Therefore, pigeonpea dehulling is not only difficult but also a specialized function when compared with other legumes. Losses of seed mass during the process of dehulling is a common event. Excluding the husk which accounts for about $15 \%$, the dhal recovery in pigeonpea is around $60 \%$ by chakki and around $70 \%$ by machines (Singh and Jambunathan, 1981). This means even by using advanced technology about $15-17 \%$ of grain mass is lost. By using chakki such losses shoot up to $20-25 \%$.

Reddy et al. (1979) studied the protein deposition pattern in pigeonpea seed and reported that the outer layers of the cotyledons are richer in protein in comparison to inner layers of seed. From nutrition point of view, this is a matter of concern since dehulling not only removes protein-rich germ but also the outer layers of the colytedons where relatively more protein constituents are housed. Fortunately, the protein quality in terms of amino acids is not adversely affected by dehulling. Singh and Jambunathan (1990) further reported that dehulling also removes about $20 \%$ calcium and $30 \%$ iron. To preserve the nutritive value of pigeonpea seed and minimizing the nutrient losses during dehulling it is essential that more efficient dehulling technology is developed and transferred to rural areas where by and large milling is still carried out by inefficient old-age techniques. According to Kurien (1981) under controlled conditions the dhal yield achieves the maximum efficiency of $80-84 \%$ but at commercial level the recovery remains around $70 \%$. He also reported large varietal differences ( 72 to $82 \%$ ) for dhal yield. Therefore, it can be assumed that with a combination of a superior variety and an efficient pigeonpea processing technology, the nutrient losses can be minimized.

\section{Cooking Quality}

Pigeonpea seeds dry, green, or processed in the form of dhal and other products are consumed after cooking. Therefore, besides various nutritional aspects the cooking time and other related parameters assume significant importance. Consumers always prefer a dhal that cooks fast and produces more volume upon cooking with high consistency and flavor. Cooking time recorded between 22 and 44 minutes for 
dhal and between 45 and 67 minutes for whole seed by Sharma et al. (1977) indicate the extent of genotypic variation present for this trait.

Cooking time of dhal was found to be independent of taste and flavor (Maninekalai et al., 1979). Jambunathan and Singh (1981) studied various physico-chemical characters in 25 pigeonpea cultivars and reported a considerable range (Table 8 ) for various quality parameters. The cooking time ranged between $24-68$ minutes. They also found that quick cooking trait was associated with large seed size, high solid dispersal, water absorption, nitrogen solubility indices, and nitrogen content of the solids dispersed. Lines with high protein and small seeds in general take more time to cook. Narsimha and Desikachar (1978), Singh et al. (1984c), and Sharma et al. (1977) reported positive association of cooking time with its calcium and magnisium contents. The issue of pre-cooking, soaking, and cooking time needs to be resolved. In

TABLE 8. Variation for various physico-chemical characteristics in 25 pigeonpea cultivars.

\begin{tabular}{lcc}
\hline Constituent & Range & Mean \\
\hline Solids dispersed (\%) & $20.8-54.7$ & 37.4 \\
Water absorption ( $\mathrm{g} \mathrm{g}^{-1}$ sample) & & \\
$\quad$ dhal & & 2.25 \\
whole grain & $1.69-2.65$ & 1.02 \\
Increase in volume $(\mathrm{v} / \mathrm{v})$ & $0.63-1.34$ & \\
$\quad$ dhal & & 1.51 \\
$\quad$ whole grain & $1.18-1.86$ & 1.13 \\
& $0.91-1.54$ & 58.6 \\
Starch (\%) & $51.5-63.4$ & 4.8 \\
Soluble sugars (\%) & $3.6-5.3$ & 36.4 \\
Nitrogen solubility index (\%) & $28.7-42.5$ & 27.3 \\
Nitrogen content in solids dispersed $(\%)$ & $19.6-31.8$ & 22.1 \\
Protein (\%) & $19.7-25.2$ & 9.6 \\
100-seed mass (g) & $6.2-20.7$ & 38 \\
Cooking time (min) & $24-68$ & \\
\hline
\end{tabular}

Adapted from Jambunathan and Singh (1981) 
some experiments pre-soaking in water reduced cooking time (ICRISAT, 1987) while in others (Saxena et al., 1992) this treatment increased the cooking time significantly. Soaking in sodium bicarbonate helped in reducing cooking time in pigeonpea but it increased $\mathrm{pH}$ and thereby adversely affected the organoleptic quality of chal.

According to Salunkhe (1982) cooking of pigeonpea improved the bioavailability of nutrients and also destroyed some antinutritional factors. Heat treatment also enhanced the starch digestibility. Lines, which take long time to cook also face the danger of loosing vital vitamins from the food. Cooking of seed after germination not only enhances the digestibility of starch (Jyothi and Reddy, 1981) but also reduces the levels of oligosaccharides (Iyenger and Kulkarni, 1977). The fermentation of seeds also helps in reducing inhibitory activity of the digestive enzymes (Rajalakshmi and Vanaja, 1967). It appears that a little research has been conducted in the past in this critical aspect of pigeonpea quality. Studies in understanding the role of various chemical constituents on cooking time in diverse genetic materials will help in resolving this issue.

Geervani (1981) studied the effect of boiling, pressure-cooking, and roasting on the quality of pigeonpea and reported that thiamine and riboflavine were destroyed by heat but niacin content was unaltered during all the treatments. Availability of lysine and methionine decreased more on roasting but the available methionine increased on boiling and pressure-cooking.

\section{Quality Losses in Storage}

Throughout the world and particularly in India and Africa, pigeonpea is predominantly cultivated by small holder resource poor farmers for meeting their domestic protein needs and to generate some income. These farmers generally store the whole seeds for about 8-12 months for sowing and round-the-year consumption. They process small quantities of grain through hand-operated mills as and when needed. In rural areas, the seeds are generally stored in gunny bags or bins made of mud and husk and during the storage period a considerable damage is caused by storage pests. Among these, bruchid (Callosabruchus spp.) is the major pest. In most cases the ripening pigeonpea pods are infested on the plants in the field and this infestation is carried to the storage bins through seeds. Since the bruchids complete their life cycle in about four weeks, they multiply fast inside the bin and cause considerable seed damage. This damage not only reduces dhal recovery and deteriorates 
germination but also adversely affects the hygine and nutritive value of seeds (Parpia, 1973). In pigeonpea, although some genotypic variation for bruchid resistance is reported (Uma Reddy and Pushpamma, 1981) but these differences are inconsistent and are not large enough to ignore the issue of storage pests.

According to the standard set by Prevention of Food Adulteration Act of 1967 , food grains containing more than $10 \mathrm{mg}$ uric acid per $100 \mathrm{~g}$ of food, arising as a result of insect infestation, are unfit for human consumption. The pigeonpea seeds when stored for five months turned unfit for consumption as their total uric acid content crossed the prescribed limit of $200 \mathrm{mg}$ per $100 \mathrm{~g}$ of sample (Daniel et al., 1977). Cooking time of food legumes in general increases with storage time and pigeonpea is no exception. Vimla and Pushpamma (1983) reported that by storing pigeonpea for eight months the safety level of uric acid was crossed. They also found that cooking time of both undamaged and damaged pigeonpea seeds increased significantly after storing them for about 12 months, indicating that even improved storage methods failed to retain the quality traits of stored seeds (Vimla and Pushpamma, 1985). Srivastava et al. (1988) reported that with the increase in insect infestation and the advancement of storage period the parameters such as seed moisture, total ash, crude fibre, protein, and reducing sugar contents increased while fat, carbohydrates, and non-reducing sugars decreased. Daniel et al. (1977) found that lysine, threonine, and protein efficiency ratios were significantly and adversely affected in pigeonpea when the seeds were stored in jute bags. Uma Reddy and Pushpamma (1981) reported significant reduction in the amino acid contents in the infested seed samples and the decline in lysine was greater than those of methionine and tryptophan. Daniel et al. (1977) observed significant decrease in the protein efficiency ratio due to storage. The storage of pigeonpea seeds also resulted in the loss of vitamins. Such losses were less (10-26\%) in the protected seed and high $(32-49 \%)$ in the unprotected infested seeds (Uma Reddy and Pushpamma, 1981). Thiamine and niacin contents also registered decline during storage. A number of factors have been identified which determine the extent of quality loss during storage. These include moisture, temperature, relative humidity, comeus thickness, hardness of grain, and ovipositional differences of storage pests (Squire, 1933; Singh et al., 1977). The storage losses can be reduced to some extent by improving the storage conditions but the decline in some quality parameters is inevitable. A well directed research is needed to provide pigeonpea farmers a cost-effective and efficient seed storing technology. 


\section{ANIMAL NUTRITION}

Pigeonpea is a wonderful plant because besides providing nutritious food for human beings it is a preferred animal fodder and feed also. Its fodder is relished by cattle, goats, and sheep while its harvest-trash, grain, and milling by-products form an excellent feed for various domestic animals.

\section{Fodder}

The perennial nature of pigeonpea plant allows it to produce tender leaves shortly after cutting the plants during its vegetative growth period and also after the harvest of seed crop. The fodder yields of pure stand cuts depend on both genotype and management practices, which include height and frequency of cuttings, availability of soil moisture and nutrition. The genotypic differences for vegetative growth have also been observed at ICRISAT. The long-duration pigeonpea cultivars that are photo-thermal sensitive produce large biomass when planted around the longest day of the year. The same genotype if planted later in the reducing daylengths produces less quantity of biomass. The selection of a suitable cultivar and appropriate agronomic management practice can produce plenty of quality forage from this crop.

Singh and Kush (1981) in India, Herrera et al. (1966) in Columbia, Parbery (1967) in Australia, and Shiying et al. (1999) in China have reported around $50 \mathrm{tha}^{-1}$ fodder yields in multiple cuttings from pigeonpea. The actual edible forage, however, is about $50 \%$ of the total yield because of the woody stem of the plant (Whiteman and Norton, 1981). Pigeonpea stands are also used for grazing purposes. In Hawaii the live-weight gain of over $1,120 \mathrm{~kg} \mathrm{ha}^{-1}$ year $^{-1}$ have been reported by Krauss (1932). Whiteman and Norton (1981) concluded that pigeonpea forage was superior to grass in gain head ${ }^{-1}$ indicating that the crop had a higher nutritive value and could carry a higher stocking rate than those of the grasses.

Generally, pigeonpea is used as forage for supplementing protein when the pasture quality is sub-standard. The young tender leaves and fresh flowers and pods form nutritive fodder for all grades of livestock. Leaves are the major forage component during the vegetative growth. As the plant approaches reproductive stage the fodder quality is enhanced due to the development of high-protein seeds. Therefore, the forage quality at a particular time will depend on the proportion of different plant parts. A proximate analysis of different pigeonpea plant 
parts as reported by various workers is summarized in Table 9. According to Krauss (1921) the fresh green foliate contain $23.7 \%$ crude protein and $35.7 \%$ fibre and seed meal has $25.3 \%$ protein and $7.3 \%$ fiber. Henke et al. (1940) compared pigeonpea fodder with other better known forage crops and concluded that pigeonpea produced the highest economic value of digestible nutrients per unit area when compared with leucern (Medicago sativa) and other species.

Whiteman and Norton (1981) conducted sheep feeding trials using pigeonpea pods and pangola grass (Digitaria decembens) in Australia. They concluded that pigeonpea pods with $7.5 \%$ crude protein fed as a sole diet were of low nutritive value and sheep lost $2 \%$ body weight. However, the inclusion of $33 \%$ of high quality forage such pangola grasses in the diet considerably improved the nutritive value of feed. They also pointed out that the harvest trash, which contains a significant proportion of leaves, would be a more nutritive feed than pods alone.

In China, pigeonpea is being promoted to meet the growing need of fresh quality fodder in the country because it can be grown well in the eroded soils of southern hilly regions for providing quality fodder under dry conditions. The ability of pigeonpea to allow 3-5 fodder cuttings within a year also makes it a useful stall-feeding crop. Pigeonpea being a perennial drought tolerant crop has shown high adaptation in a range of soil types of mountain regions of $\mathrm{Du} \mathrm{Au,} \mathrm{Dahua,} \mathrm{Huan} \mathrm{Jiang,} \mathrm{and}$ Feng Shan counties of Guangxi province of China. According to Fuji

TABLE 9. Major nutrition constituents in different pigeonpea plant parts.

\begin{tabular}{lcccccl}
\hline Component & $\begin{array}{c}\text { Crude } \\
\text { protein } \\
(\%)\end{array}$ & $\begin{array}{c}\text { Crude } \\
\text { fiber } \\
(\%)\end{array}$ & $\begin{array}{c}\text { N-free } \\
\text { extract } \\
(\%)\end{array}$ & $\begin{array}{c}\text { Fat } \\
(\%)\end{array}$ & $\begin{array}{c}\text { Ash } \\
(\%)\end{array}$ & Reference \\
\hline Fresh green forage & 23.7 & 35.7 & 26.3 & 5.3 & 8.7 & Krauss (1921) \\
Whole tops, mature & 18.8 & 29.4 & 40.0 & 5.2 & 5.6 & Work (1946) \\
Whole tops, young & 15.8 & 31.2 & 37.7 & 4.6 & 5.6 & Work (1946) \\
Seed meal & 25.3 & 7.3 & 61.2 & 1.7 & 4.1 & Krauss (1921) \\
Mature dry seed & 21.3 & - & 63.7 & 1.7 & 4.2 & Morion (1976) \\
Pod meal & 10.1 & 40.7 & 45.0 & 1.6 & 3.1 & Krauss (1921) \\
Pods intact & 7.0 & - & 42.8 & 0.4 & 5.7 & Morton (1976) \\
\hline
\end{tabular}


and Zhanghong (1995) the foliage of pigeonpea is a quality fodder and goats, buffalo, cattle, and pig relish it.

A preliminary evaluation of ICRISAT pigeonpea varieties at Guangxi Academy of Agricultural Sciences in China showed that with multiple cuttings within a year variety ICPL 93047 produced $54 \mathrm{t} \mathrm{ha}^{-1}$ of fresh and $29 \mathrm{t} \mathrm{ha}^{-1}$ of dry fodder (Shiying et al., 1999). This experiment also showed that pigeonpea could grow well during winter and can meet the fodder needs when normal fodder supply is limited. It was observed that the goats and cattle liked the dry forage of pigeonpea better than green matter. S.C. Rao (Personal communication) compared tall and dwarf pigeonpea lines for forage production and their nutrition value in the southern plains of USA and reported that the dwarf genotype (PBNA) produced tender branches resulting in relatively less stem dry matter. In comparison to tall types $\left(23 \mathrm{~g} \mathrm{~kg}^{-1}\right)$ the dwarf line produced greater (28.6 $\left.\mathrm{g} \mathrm{kg}^{-1}\right)$ nitrogen. The digestibility of the forage harvested from the dwarf line was also greater than the tall genotypes.

\section{Feed}

Whole grain, threshing trash and milling by-products are used as feed for cattle, poultry, and pigs. These pigeonpea by-products provide protein-rich substitute for domestic animals at cheaper rates. In countries where climate is hot and dry and other legume crops are difficult to grow, pigeonpea is an attractive alternative. In the first quarter of 20 th century pigeonpea was extensively used as poultry meal in Hawaii. According to Krauss (1932) an equal mixture of cracked pigeonpea and cracked maize seed was considered the best poultry ration. Draper (1944), Springhall et al. (1974), and Wallis et al. (1986) considered pigeonpea as an ideal protein substitute for all types of poultry rations. Since whole pigeonpea seeds contain some amount of antinutritional factors heat treatment of grains was introduced in the animal ration preparations. This resulted in a significant increase in the apparent metabolizable energy content of pigeonpea meal (Nowkolo and Oji, 1985). Wallis et al. (1986) reported little effect of heating on growth rates, feed intake, and in feed conversion efficiency. Falvey and Visitpanich (1980) conducted pig-feeding trials using $30 \%$ ground pigeonpea seed in Thailand. They reported live-weight gain from $25 \mathrm{~g} \mathrm{day}^{-1}$ to $159 \mathrm{~g}^{\text {day }}{ }^{-1}$. By using boiled pigeonpea the live-weight gain was further increased to $205 \mathrm{~g} \mathrm{day}^{-1}$. This increase was attributed to the reduction of trypsin inhibitor activity that in turn improved the feed conversion ratio. The re- 
cently bred high-protein pigeonpea lines at ICRISAT are likely to enhance the utility of pigeonpea in animal ration.

Use of pigeonpea seeds as feed is a common practice in rural China and it is primarily fed to pigs and chickens and some times to cattle and goats also. For pigs, the boiled seeds of pigeonpea are used to prepare feed mixtures with other ingredients while raw seeds are fed to chickens. In 1992, Research Institute of Resource Insects in China studied the nutritional value of pigeonpea feed. In this experiment pigs were fed with feed mixtures prepared with different concentrations of pigeonpea (Fuji et al., 1995). They found that a mixture with 6-12\% pigeonpea in the meal mixture, the gain in the meat-mass production was $78 \mathrm{~g} \mathrm{day}^{-1}$ with a ratio of meat-mass to feed input of $3.54: 1$ and this efficiency-mark meets the Chinese National Standards. Based on this information, Fuji et al. (1995) developed various feed mixtures using pigeonpea seed (22\% protein) and dry leaf powder (19\% protein) as major source of protein.

As mentioned earlier that in India over 3 million tons of pigeonpea is converted into dhal annually by processing either at household level by chakki or at commercial mills. This conversion of whole dry seeds into dhal yields significant quantity (about $30 \%$ ) of the by-products. These include approximately $3-8 \%$ brokens, $15 \%$ powder, and $10 \%$ husk. The powder and brokens are important source of protein for cattle feed (Pathak, 1970). Whiteman and Norton (1981) evaluated non-seed material collected from machine harvester and reported that it contains $13.9 \%$ crude protein, $0.35 \%$ phosphorus, $0.06 \%$ sulfur, and $7.3 \%$ ash. This ration when fed sole was inadequate for live-weight maintenance and they attributed it to its low sulfur content which is associated with nitrogen requirement of cattle and suggested that sulfur supplement is essential for utilization of this forage.

\section{GENETIC ENHANCEMENT OF PROTEIN}

Increasing yielding capacity of the food crops is the primary task of plant breeders and production of varieties resistant to diseases and pests is their perennial target. As for as demand for quality is concerned, it assumes importance after a certain quantitative level of food production has been achieved. In most third world countries food supplies have not kept pace with the rising population and therefore quality breeding never reached a priority level in any institution. Considering the state of malnutrition in most developing and under-developed countries and the 
role pigeonpea can play in subsistence farming, the genetic enhancement of protein content in pigeonpea is a logical approach for addressing this issue. A small increase in protein content of the adapted cultivars will lead to significant protein yield on a sustainable basis. For increased adoption of the enhanced-protein cultivars it is essential that they perform as good as normal cultivars in most agronomic traits such as seed size, disease resistance, and yield. This will ensure adequate returns to farmers. Since ICRISAT has global responsibility for pigeonpea improvement, it took this challenge and a project on breeding high-protein lines was implemented. To have an effective breeding program studies on genetic control were also conducted to develop efficient breeding methodology and selection and testing procedures. The results are discussed herein.

\section{Genetic Control of Protein Content}

Information on the genetic control of protein content in pigeonpea is limited. Saxena and Sharma (1990), while reviewing the subject, reported the presence of both additive and non-additive genetic variation in determining protein content in pigeonpea and this variation was found to be controlled by 3-4 genes (Dahiya et al., 1977). Reddy et al. (1979) reported that the magnitude of heterosis for protein was in the negative direction. Dahiya and Brar (1977) reported strong maternal influence in determining protein content of seed.

For better understanding of the nature of genetic parameters the parents should have a large variation for the traits. Since the genetic material used in earlier genetic studies had limited variability for protein, Durga (1989) conducted genetic analysis for protein in two high (30-31\% protein), two medium (26-27\% protein), and two low (22-23\% protein) lines of pigeonpea to develop basic information on various genetic parameters. She concluded that (i) reciprocal differences in $F_{1}$ generation for protein were large, (ii) protein content was under additive and complementary gene effects, (iii) low-protein content was dominant or partially dominant over high-protein content, and (iv) protein content had moderately high $(65.2 \%)$ narrow-sense heritability.

\section{Breeding Methodology}

As the first step in breeding for high protein, a search for high-protein trait was made in literature and in the pigeonpea germplasm available in ICRISAT gene bank. Swaminathan (1973) analyzed about 2000 pigeon- 
pea germplasm and reported little variation for protein content. Although significant genotypic differences were reported for protein content in some studies (Yadav, 1984; Esh et al., 1959), the variation was not found large enough to allow selection of lines within the germplasm. Further, it was also noticed that the reported observations were based on single year data and perhaps had significant confounded influence of the sampling and environment. Considering all the factors together, it was decided to search for high-protein trait in the secondary gene pool and use them in breeding program. Since all the wild relatives of pigeonpea cannot be crossed with cultivated types, only the crossable species were examined. The results indicated that Cajanus sericeus, $C$. lineatus, and $C$. scarabaeoides had high-protein (Table 10). The dhal protein levels in this group ranged up to $31 \%$. Therefore, these were selected as donor parents for hybridization. Breeding for high protein was carried out using pedigree method. Since the wild relatives of pigeonpea differ grossly from the cultivated types with respect to all agronomic traits and are unfit for cultivation and consumption, a breeding strategy was developed to select simultaneously for improved agronomic traits and high protein content.

TABLE 10. Protein content and seed size of high-protein lines and their parents.

Species/genotype Protein

$(\%)$

Cultivated species

Baigani

Pant A-2

T.21

Wild species

C. scarabaeoides

C. sericea

C. albicans

High-protein lines

HPL 2

HPL 7

HPL 40

HPL 51
23.7

22.7

24.4
28.4

29.4

30.5
29.0

28.0

27.0

27.9 100-seed mass

(g)

11.2

7.5

7.5
Protein seed -1

(mg)

26.5

17.0

18.3

Adapted from Saxena et al. (1987a)

2.3

1.9

2.8
6.5

5.6

8.5
12.1

10.0

10.4

10.6
35.1

28.0

28.1

29.6 


\section{Hybridization and Selection}

Crosses were made using the wild relative as female parent. In the subsequent segregating generation $\left(\mathrm{F}_{2}\right)$, as expected, a large variation was observed for plant type and seed characters. In each cross over 200 plants were examined for protein content and the segregants with desirable protein content were selected. In each subsequent generation the individuals with improved plant type were selected in field and the final selection of the single plants for generation advance was done after determining their protein content in the laboratory. Each plant sample was evaluated in duplicate and compared with a control cultivar grown in the same field. The selected plants were ratooned and selfed using muslin cloth bags to harvest genetically pure seed. After 10 generations of pedigree selection simultaneously for agronomic traits in field and seed characters in laboratory, several breeding lines were identified (Tables 10 and 11). In these selections the high-protein trait of the wild relative of pigeonpea and seed characters of cultivated type were recovered.

TABLE 11. Performance of some high-protein pigeonpea selections at Patancheru.

\begin{tabular}{|c|c|c|c|c|c|}
\hline \multirow[t]{2}{*}{ Year/line } & \multirow{2}{*}{$\begin{array}{l}\text { Days to } \\
\text { mature }\end{array}$} & \multirow{2}{*}{$\begin{array}{l}100-\text { seed } \\
\text { mass }(\mathrm{g})\end{array}$} & \multirow{2}{*}{$\begin{array}{c}\text { Grain yield } \\
\left(\mathrm{t}^{2} \mathrm{a}^{-1}\right)\end{array}$} & \multicolumn{2}{|c|}{ Protein } \\
\hline & & & & $(\%)$ & $\left\langle\mathrm{kg} \mathrm{ha}^{-1}\right\rangle$ \\
\hline \multicolumn{6}{|l|}{1985} \\
\hline $\begin{array}{l}\text { HPL 40-5 } \\
\text { HPL 40-17 }\end{array}$ & $\begin{array}{l}169 \\
169\end{array}$ & $\begin{array}{l}9.6 \\
8.5\end{array}$ & $\begin{array}{l}2.10 \\
2.07\end{array}$ & $\begin{array}{l}26.9 \\
26.5\end{array}$ & $\begin{array}{l}452 \\
440\end{array}$ \\
\hline BDN 1 (control) & 168 & 9.6 & 2.02 & 23.2 & 373. \\
\hline $\begin{array}{l}\mathrm{SE} \\
\mathrm{CV} \%\end{array}$ & $\begin{array}{r} \pm 0.9 \\
0.9\end{array}$ & $\begin{array}{c} \pm 0.18 \\
3.4\end{array}$ & $\begin{array}{l} \pm 0.18 \\
17.3\end{array}$ & $\begin{array}{c} \pm 0.46 \\
3.0\end{array}$ & $\begin{array}{r} \pm 37.3 \\
17.0\end{array}$ \\
\hline \multicolumn{6}{|l|}{1986} \\
\hline $\begin{array}{l}\text { HPL 8-10 } \\
\text { HPL 8-16 }\end{array}$ & $\begin{array}{l}163 \\
162\end{array}$ & $\begin{array}{l}10.5 \\
10.5\end{array}$ & $\begin{array}{l}1.66 \\
1.57\end{array}$ & $\begin{array}{l}26.5 \\
27.4\end{array}$ & $\begin{array}{l}353 \\
344\end{array}$ \\
\hline ICPL 211 (control) & $162^{\circ}$ & 14.3 & 1.46 & 21.6 & 251 \\
\hline $\begin{array}{l}\mathrm{SE} \\
\mathrm{CV} \%\end{array}$ & $\begin{array}{r} \pm 1.1 \\
1.3\end{array}$ & $\begin{array}{c} \pm 0.15 \\
2.5\end{array}$ & $\begin{array}{l} \pm 0.19 \\
27.0\end{array}$ & $\begin{array}{c} \pm 0.21 \\
1.7\end{array}$ & $\begin{array}{r} \pm 38.5 \\
25.8\end{array}$ \\
\hline
\end{tabular}




\section{Relationship Between Seed Size and Protein}

In pigeonpea, seed size is an important parameter from consumption and dehulling points of view. Negative correlations between seed size and protein have been reported in cereals such as pearl millet (Kumar et al., 1983) and sorghum (Wayne and Casady, 1974) and legumes (Blixt, 1979; Imam, 1979). In pigeonpea, Dahiya and Brar (1976) found no association between seed size and protein in 220 germplasm accessions, while Reddy et al. (1979) reported negative association between these two variables in inter-specific derivatives. Saxena et al. (1987b) while studying this relationship in 192 pigeonpea cultivars, found that the association between seed size and protein content was negative and partly controlled by genetic factors. Therefore, at the commencement of the project, aimed to develop high-protein lines in pigeonpea, there was some concern that the high-protein level of the wild species donors would remain associated with small seed size and antinutritional factors in the derived lines. According to Bahl et al. (1979) a negative relationship between seed size and protein was a result of the deposition of an increased amount of starch in seed which alters the starch:protein ratio. However, it has been found in Vicia faba (Abo-Hegazi, 1979), Phaseolus vulgaris (Gridley and Evans, 1979), and soybean (Hartwig and Hinson, 1972) that the negative correlation could be changed through breeding and selection of exceptional genotypes in segregating generations that appeared more efficient than expected in their protein synthesis and combine superior agronomic traits is possible.

The estimates of correlation between seed size and protein obtained in the breeding materials developed at ICRISAT indicated that in pigeonpea improved seed size and protein can be selected simultaneously (Saxena et al., 1987c). From the inter-specific crosses, some promising high-protein lines identified are HPL 2, HPL 7, HPL 40, and HPL 51 (Table 10). These lines combined high-protein and large seed size (Figure 2).

\section{Agronomic Evaluation of High-Protein Lines}

In pigeonpea, seed size is also associated with yield. Sharma and Saxena (1977) showed that these two variables are independent of each other in the 100-seed mass range of 9-12 g. This relationship, however, was positive in small seeded materials and negative in the materials larger than the seed size range indicated above. These observations in- 
FIGURE 2. Seeds and pods of wild relative of pigeonpea (right), high-protein line (middle), and control cultivar (left)

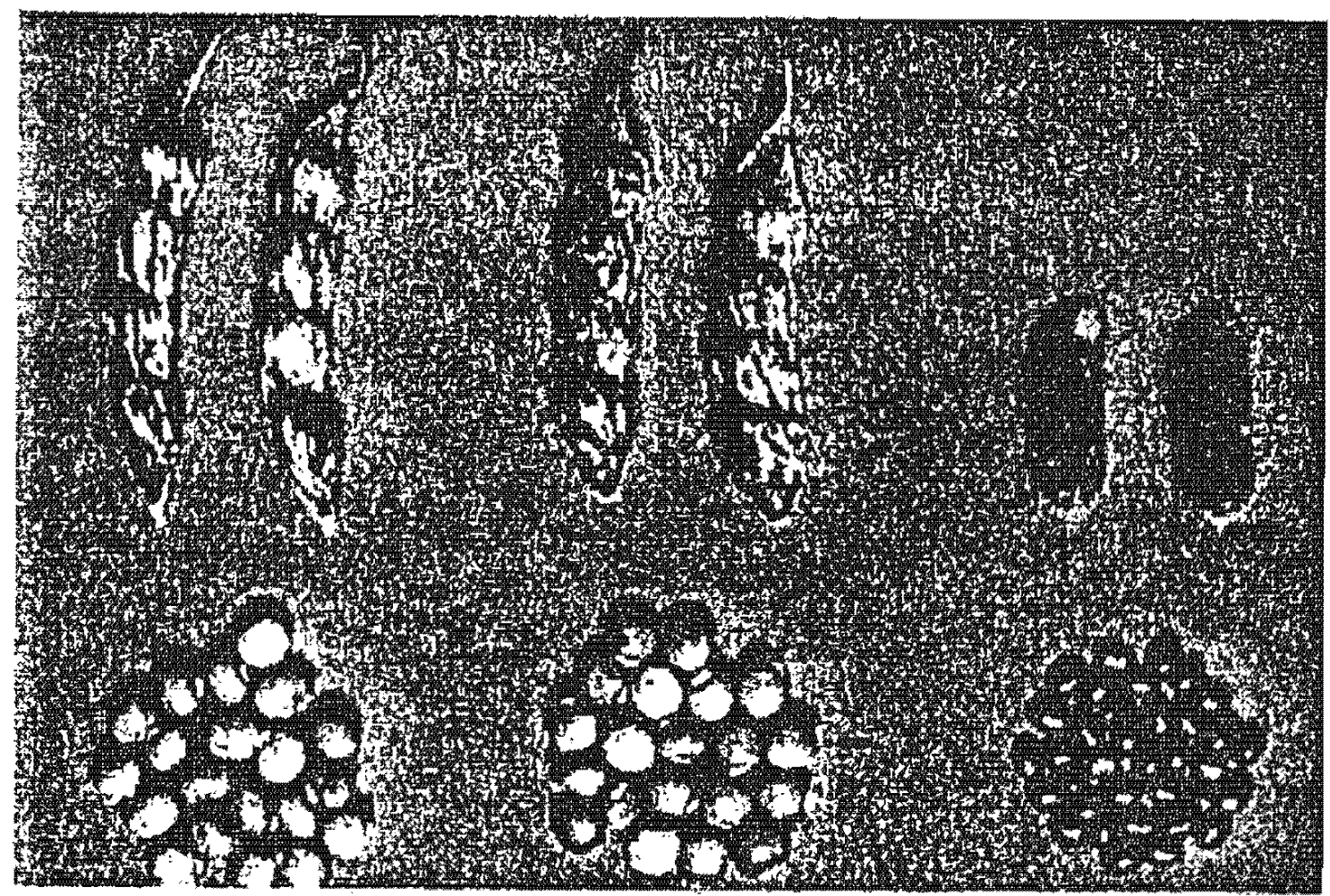

dicated that within the medium seed size range simultaneous improvement for seed protein, seed size as well as yield could be made.

The results of agronomic evaluation of the promising high-protein selections were very encouraging (Table 11). The high-protein selections were found similar to the control cultivars in important agronomic traits such as days to maturity, seed size, and dry seed yield. For protein content the selections were significantly superior to the controls and their protein content ranged between $26-27 \%$. An estimate of total protein harvest in this trial revealed that by growing these high-protein lines in one hectare about $350-450 \mathrm{~kg}$ crude protein could be harvested. These values reflect the additional advantage of $80-100 \mathrm{~kg}_{\text {protein }} \mathrm{ha}^{-1}$. Cultivation of these lines will markedly improve availability of the nutritive protein to the farmers without sacrificing the seed yield.

\section{Nutritional Quality of High-Protein Lines}

Since the high-protein trait in pigeonpea was transferred using traditional breeding methods from its wild relatives, known to possess various antinutritional factors, it was necessary to compare the derived lines with traditional cultivars for various nutritional quality parameters be- 
fore releasing them for human or animal consumption. For this purpose, Singh et al. (1990) compared two high-protein lines (HPL 8 and HPL 24) with two control cultivars (C 11 and ICPL 211). The main findings are discussed below.

Chemical composition: There were large differences between the protein levels of high-protein lines (28.7 to $31.1 \%$ ) and control cultivars (23.1 to $24.8 \%$ ). As expected the starch component $(54.3$ to $55.6 \%$ ) of the high-protein lines was relatively less than that of controls (58.7 to $59.3 \%$ ). Also the high-protein lines ( 2.5 to $2.6 \%$ ) were marginally lower in fat content when compared with control cultivars (2.9 to $3.1 \%$ ). The differences in the major protein fractions of the high and normal-protein lines were large. In comparison to controls $(60.3$ to $60.5 \%)$, the globulin fraction was higher (63.5 to $66.2 \%$ ) in the high-protein lines and the reverse was true for glutelin (Table 12). This variation in the storage proteins, however, was not large enough to influence the amino acid profiles of high and normal-protein lines (Singh et al., 1990). Also the activities of trypsin and chymotrypsin inhibitors were found more or less similar in the high-protein lines and the controls.

Biological evaluation: A series of rat feeding trials and laboratory

TABLE 12. Comparison of high-protein lines and control cultivars for starch, major protein fractions, and sulphur containing amino acids.

\begin{tabular}{|c|c|c|c|c|c|}
\hline \multirow{2}{*}{ Constituent } & \multicolumn{2}{|c|}{ High-protein lines } & \multicolumn{2}{|c|}{ Controls } & \multirow{2}{*}{ SE } \\
\hline & HPL 8 & HPL 40 & $\mathrm{CH}$ & ICPL 211 & \\
\hline Starch $^{1}$ & 54.3 & 55.6 & 58.7 & 59.3 & \pm 0.30 \\
\hline Protein 1 & 28.7 & 31.1 & 24.8 & 23.1 & \pm 0.09 \\
\hline Albumin ${ }^{2}$ & 9.1 & 8.0 & 7.7 & 8.6 & \pm 0.34 \\
\hline Globulin ${ }^{2}$ & 63.5 & 66.2 & 60.5 & 60.3 & \pm 1.08 \\
\hline Prolami2 & 2.9 & 3.2 & 3.6 & 2.1 & \pm 0.06 \\
\hline Glutelin $^{2}$ & 20.2 & 19.7 & 23.3 & 22.8 & \pm 0.75 \\
\hline Methionine ${ }^{2}$ & 1.0 & 1.0 & 1.1 & 1.1 & \pm 0.02 \\
\hline Cystine ${ }^{2}$ & 0.8 & 0.8 & 0.7 & 0.7 & \pm 0.01 \\
\hline
\end{tabular}

Adapted from Singh et al. (1990)

1: $\left(\mathrm{g} 100^{-1} \mathrm{~g}\right.$ dhat

2: (g $100^{-1} \mathrm{~g}$ protein) 
evaluations were conducted to assess various nutritional parameters for the high-protein lines. The raw seeds and cooked dhal samples from the high and normal-protein lines were found more or less similar in true protein digestibility, biological value, and net protein utilization. However the high-protein lines were found significantly superior in utilizable protein (Table 13). Singh et al. (1990) concluded that the high-protein lines are nutritionally superior to normal-protein cultivars as the former contain quantitatively more utilizable protein and sulfur containing amino acids. The whole seeds of the high-protein lines for animals and their dhal for human beings is nutritionally beneficial and its promotion will help in addressing the nutritional issues in rural areas.

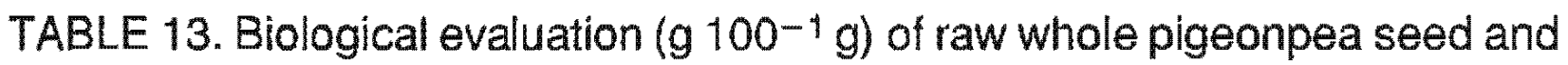
cooked dhal samples of high-protein selections and normal-protein control cultivars.

\begin{tabular}{|c|c|c|c|c|c|}
\hline \multirow{2}{*}{ Parameter } & \multicolumn{2}{|c|}{ High-protein lines } & \multicolumn{2}{|c|}{ Control cultivars } & \multirow{2}{*}{ SE } \\
\hline & HPL 8 & HPL 40 & $C 11$ & ICPL 211 & \\
\hline \multicolumn{6}{|c|}{ Raw whole seed } \\
\hline Protein & 25.6 & 27.3 & 21.9 & 21.0 & \pm 0.48 \\
\hline TO & 58.5 & 58.0 & 59.5 & 60.6 & \pm 1.08 \\
\hline BV & 68.7 & 70.5 & 64.3 & 64.0 & \pm 1.13 \\
\hline NPU & 40.2 & 40.9 & 38.3 & 38.8 & \pm 0.64 \\
\hline UP & 10.3 & 11.2 & 8.4 & 8.1 & \pm 0.23 \\
\hline \multicolumn{6}{|c|}{ Cooked chal } \\
\hline Protein & 27.6 & 30.8 & 23.9 & 22.8 & \pm 0.26 \\
\hline TD & 83.7 & 82.9 & 84.3 & 85.7 & \pm 2.14 \\
\hline BV & 67.0 & 65.3 & 66.7 & 62.9 & \pm 1.68 \\
\hline NPU & 56.1 & 54.1 & 56.2 & 53.9 & \pm 1.06 \\
\hline UP & 15.5 & 16.7 & 13.5 & 12.3 & \pm 0.25 \\
\hline $\begin{array}{l}\text { TD : True pr } \\
\text { BV : Biologi } \\
\text { NPU: Net pro } \\
\text { UP : Utilizat } \\
\text { Adapted from }\end{array}$ & & & & & \\
\hline
\end{tabular}




\section{GENOTYPE-ENVIRONMENT INTERACTION FOR SEED PROTEIN}

Environment plays a significant role in the expression of both morphological and biochemical traits in crop plants. Some characters such as seed size show less environmentally induced variability while others exhibit relatively large variation and the seed protein belongs to the later group. The observed variation for protein over locations could be influenced by environment where it is grown including the soil type and its moisture and nutrient level. Some sites favor higher nitrogen accumulation in seed as compared to others and such marked differences have been demonstrated in almost all the cereals and legumes. Hamilton et al. (1951) observed a linear relationship between protein accumulation and the increase in the alcohol-soluble protein fraction of the total protein in maize. This resulted in reduced biological value of protein as neither lysine nor tryptophan is alcohol-soluble protein.

In crops like pigeonpea where flowering is determined by photoperiod and temperature, the rate of development and duration of vegetative and reproductive periods vary widely. The meteorological conditions of certain months may exert diverse effects on the nutritional metabolism in the varieties, thus influencing the crude protein content of seeds. Pietri et al. (1971) found no response of fertilization on protein content of pigeonpea while Sham (1976), Singh et al. (1974), and Esh et al. (1959) reported significant effects of location and fertilizer application on pigeonpea seed protein. Oke (1969) reported that incorporation of 20 ppm sulfur alone or in combination with phosphorus increased methionine content of pigeonpea. Jain et al. (1986) observed significant effect of location in the advanced breeding lines of short and medium maturity duration. Singh et al. (1984c) reported significant effects of growing season (rainy and post-rainy) on various quality parameters.

Saxena et al. (1984) reported the results of an extensive study conducted by ICRISAT in 1975 to characterize environmental variation for protein content in six pigeonpea cultivars at Hyderabad $\left(17^{\circ} \mathrm{N}\right)$, Sehore $\left(24^{\circ} \mathrm{N}\right)$, Mandasore $\left(25^{\circ} \mathrm{N}\right)$, Pantnagar $\left(29^{\circ}\right)$, and Hisar $\left(29^{\circ}\right)$. At each location the plantings were done in different (4-12) months. They observed large and significant differences among locations and among months with in a location (Table 14). In general, the protein levels were high at higher latitudes. Within a variety grown at a particular location in different months, the variation for protein was also large. For example, in cv. 'Prabhat', planted at Hyderabad over 12 months, the seed protein content ranged from 21.6 to $25.2 \%$; similarly at Pantnagar in 10 
TABLE 14. Variation for dhalprotein (\%) in six pigeonpea cultivars planted in various months at different locations during 1975.

\begin{tabular}{|c|c|c|c|c|c|c|}
\hline $\begin{array}{l}\text { Cultivar } \\
(\%)\end{array}$ & Location & $\begin{array}{l}\text { No. of } \\
\text { months }\end{array}$ & Mean & Range & Variance & C.V. \\
\hline Prabhat & $\begin{array}{l}\text { Hyderabad } \\
\text { Pantragar } \\
\text { Sehore } \\
\text { Hisar } \\
\text { Mandsore }\end{array}$ & $\begin{array}{r}12 \\
10 \\
6 \\
6 \\
7\end{array}$ & $\begin{array}{l}23.4 \\
25.9 \\
23.0 \\
25.3 \\
24.5\end{array}$ & $\begin{array}{l}21.6-25.2 \\
24.5-27.9 \\
20.9-25.2 \\
24.3-27.0 \\
23.2-26.2\end{array}$ & $\begin{array}{l}1.93 \\
1.41 \\
2.24 \\
0.95 \\
0.90\end{array}$ & $\begin{array}{l}5.94 \\
4.59 \\
6.52 \\
3.85 \\
3.88\end{array}$ \\
\hline Pusa Ageti & $\begin{array}{l}\text { Hyderabad } \\
\text { Pantnagar } \\
\text { Sehore } \\
\text { Hisar } \\
\text { Mandsore }\end{array}$ & $\begin{array}{r}12 \\
7 \\
8 \\
6 \\
6\end{array}$ & $\begin{array}{l}23.8 \\
26.7 \\
23.9 \\
24.9 \\
25.1\end{array}$ & $\begin{array}{l}21.0-26.4 \\
24.7-29.3 \\
22.1-25.4 \\
24.2-25.4 \\
23.7-26.6\end{array}$ & $\begin{array}{l}2.34 \\
2.73 \\
1.29 \\
0.18 \\
1.31\end{array}$ & $\begin{array}{l}6.45 \\
6.19 \\
4.76 \\
1.72 \\
4.56\end{array}$ \\
\hline T. 21 & $\begin{array}{l}\text { Hyderabad } \\
\text { Paninagar } \\
\text { Sehore } \\
\text { Hisar } \\
\text { Mandsore }\end{array}$ & $\begin{array}{r}12 \\
8 \\
10 \\
4 \\
8\end{array}$ & $\begin{array}{l}24.3 \\
26.8 \\
22.8 \\
25.1 \\
26.2\end{array}$ & $\begin{array}{l}22.3-26.4 \\
25.6-28.6 \\
20.2-24.4 \\
24.3-25.7 \\
24.5-28.2\end{array}$ & $\begin{array}{l}2.43 \\
0.81 \\
1.52 \\
0.33 \\
1.79\end{array}$ & $\begin{array}{l}6.41 \\
3.36 \\
5.40 \\
2.29 \\
5.10\end{array}$ \\
\hline No. 148 & $\begin{array}{l}\text { Hyderabad } \\
\text { Pantnagar } \\
\text { Sehore } \\
\text { Hisar } \\
\text { Mandsore }\end{array}$ & $\begin{array}{r}12 \\
4 \\
9 \\
6 \\
8\end{array}$ & $\begin{array}{l}24.0 \\
26.4 \\
23.9 \\
25.2 \\
25.0\end{array}$ & $\begin{array}{l}20.7-26.8 . \\
25.3-28.1 \\
22.1-26.2 \\
24.0-26.3 \\
23.5-25.8\end{array}$ & $\begin{array}{l}2.79 \\
1.43 \\
1.58 \\
0.79 \\
0.72\end{array}$ & $\begin{array}{l}6.96 \\
4.53 \\
5.25 \\
3.52 \\
3.40\end{array}$ \\
\hline ST 1 & $\begin{array}{l}\text { Hyderabad } \\
\text { Panthagar } \\
\text { Sehore } \\
\text { Hisar } \\
\text { Mandsore }\end{array}$ & $\begin{array}{r}12 \\
7 \\
9 \\
6 \\
7\end{array}$ & $\begin{array}{l}23.6 \\
26.5 \\
22.8 \\
25.3 \\
24.8\end{array}$ & $\begin{array}{l}22.3-24.6 \\
24.5-27.5 \\
19.8-25.6 \\
24.4-26.2 \\
21.4-27.4\end{array}$ & $\begin{array}{l}0.56 \\
0.95 \\
3.29 \\
0.56 \\
4.45\end{array}$ & $\begin{array}{l}3.18 \\
3.68 \\
7.97 \\
2.96 \\
8.50\end{array}$ \\
\hline PDM 1 & $\begin{array}{l}\text { Hyderabad } \\
\text { Pantrnagar } \\
\text { Sehore } \\
\text { Hisar } \\
\text { Mandsore }\end{array}$ & $\begin{array}{r}12 \\
6 \\
8 \\
5 \\
7\end{array}$ & $\begin{array}{l}23.6 \\
26.4 \\
24.1 \\
26.5 \\
23.9\end{array}$ & $\begin{array}{l}20.1-26.9 \\
25.4-28.1 \\
20.7-26.4 \\
24.9-27.6 \\
22.1-26.1\end{array}$ & $\begin{array}{l}4.15 \\
1.01 \\
4.31 \\
1.13 \\
3.44\end{array}$ & $\begin{array}{l}8.63 \\
3.82 \\
8.62 \\
4.01 \\
7.74\end{array}$ \\
\hline
\end{tabular}

plantings within a year the protein content of $\mathrm{cv}$. Prabhat ranged from 24.5 to $27.9 \%$. Besides environments, the pigeonpea lines used in this study differed considerably in their response to photoperiod and temperature and this caused a large variation in flowering and maturity. Therefore no attempt was made to identify the effect of any particular location, date of planting or any other specific factor on the protein values. The differences observed in maximum and minimum protein values within varieties amply demonstrated that the environment could 
have a significant role in determining the seed protein content in pigeonpea.

Genotype-environment interaction in the high-protein lines developed at ICRISAT was also studied (Saxena et al., 1987a). The replicated trials were conducted at six locations. Although statistically significant genotype-environment interactions were recorded, the highprotein lines recorded significantly superior protein content to controls. For example in HPL 24 the protein ranged between 30.9 to $32.3 \%$ while in control it ranged between 21.4 to 24.5 (Table 15). The data also showed that the extent of variation for protein-content was more or less similar in high-protein lines and control cultivar, but the high-protein trait was maintained at each location. A summary of performance of the

TABLE 15. Protein content of high-protein selections at different locations during 1985 and in different years at Patancheru.

\begin{tabular}{lcccccc}
\hline Locations/year & HPL24 & HPL 25 & HPL 26 & HPL 28 & Control & SE \\
\hline Locations in 1985 & & & & & & \\
Patancheru & 31.3 & 28.6 & 29.7 & 27.8 & 23.3 & \pm 0.26 \\
Jalna & 32.2 & 28.9 & 29.7 & 30.4 & 23.1 & \pm 0.69 \\
SK Nagar & 30.9 & 28.4 & 29.0 & 27.3 & 21.4 & \pm 0.36 \\
Gulburga & 32.1 & 29.9 & - & 27.6 & 23.0 & \pm 0.49 \\
Gwalior & 32.3 & 30.4 & 28.2 & 27.3 & 22.0 & \pm 0.71 \\
Hisar & 31.1 & 29.6 & 31.7 & 29.2 & 24.5 & - \\
Years at Patancheru & & & & & & \\
1981 & 28.3 & 28.3 & 27.6 & 27.6 & 20.9 & - \\
1982 & 33.1 & 31.8 & 30.9 & 31.8 & 22.6 &. \\
1983 & 29.3 & 29.8 & 29.7 & 29.5 & 23.6 & - \\
1984 & 33.8 & 31.6 & 30.7 & 31.4 & 22.7 & - \\
1985 & 31.4 & 29.1 & 29.0 & 27.9 & 22.9 & - \\
1986 & 32.6 & 31.4 & 30.9 & 29.2 & 23.3 & - \\
Mean & 31.4 & 30.3 & 29.8 & 29.6 & 22.7 & - \\
\hline
\end{tabular}


high-protein lines grown at Patancheru (Table 15) for six years indicated significant year-to-year variation. For example in 1982, 1984, and 1986 relatively high-protein estimates were recorded and in 1981 the estimates were relatively low. In spite of such variation over the years the superiority of high protein line was maintained.

\section{REFERENCES}

Abo-Hegazi, A.M.T. 1979. High protein lines in field beans Vicia faba from a breeding programme using gamma ray: 1 . Seed yield and heritability of seed protein. pp. 33-36. In Proc. Symp. Seed Protein Impr. Cereals and Grain Legumes. Vol. II, IAEA, FAO and GSF. Neuherberg; Federal Republic of Germany.

Ambekar, S.S., S.C. Patil, A.P. Giri, and M.S. Kachole 1996. Trypsin and amylase inhibitors in pigeonpea seeds. Int. Chickpea and Pigeonpea Newsletter 3:106-107.

Bahl, P.N., S.P. Singh, H. Ram, D.B. Raju, and H.K. Jain. 1979. Breeding for improved plant architecture and high protein yields. pp. 297-306. In Proc. Symp. Seed Protein Impr. Cereals and Grain Legumes. VoL. I, IAEA, FAO and GSF. Neuherberg, Federal Republic of Germany.

Bidinger, P.D., and B. Nag. 1981. The role of pigeonpeas in village diets. pp. 357-364. Iit Proc. Int. Workshop Pigeonpeas, Vol. 1, 15-19 December 1980, ICRISAT Center, India. Patancheru, A.P., India.

Blixt, S. 1979. Natural and induced variability for seed protein in temperate legumes. pp. 3-21 In Proc. Symp. Seed Protein Impr. Cereals and Grain Legumes. Vol. II, IAEA, FAO and GSF. Neuherberg, Federal Republic of Gernany.

Dahiya, B.S., and J.S. Brar. 1976. The relationship between seed size and protein content in pigeonpea (Cajanus cajan (L.) Millsp.). Trop. Grain Legume Bull. 3:18-19.

Dahiya, B.S., and J.S. Brar. 1977. Diallel analysis of genetic variation in pigeonpea (Cajanus cajan). Exptl. Agric. 13 (2):193-200.

Dahiya, B.S., J.S. Brar, and B.S. Bhullar. 1977. Inheritance of protein content and its correlation with grain yield in pigeonpea (Cajants cajan (L.) Millsp.). Qual. Plant Pl. Food. Hum. Nutri. 27 (3-4):327-334.

Daniel, V.A., D. Narayanaswamy, B.L.M. Desai, S. Kurien, M. Swaminathan, and H.A.B. Parpia. 1970. Supplementary value of varying levels of red gram (Cajanus cajan) to poor diets based on rice and ragi. Ind. J. Nutr. Dietet. 7:358-362.

Daniel, V.A., P. Rajan, K.V. Sanjeevarayappa, K.S. Srinivasan, and M. Swaminathan. 1977. Effect of insect infestation on the chemical composition and the protein efficiency ratio of the proteins of Bengal gram and red gram. Ind. J. Nutr. Dietet. $14: 70.74$.

Draper, C.I. 1944. Algaroba beans, pigeonpeas and processed garbage in the layingmash. Hawaii Agrl. Exp. Sta. Prog. Rept. 44. Uni. of Hawaii, Honolulu, Hawaii, USA.

Durga, B.K. 1989. Genetic studies on protein content and nitrogen accumulation in pigeonpea. Ph.D. Thesis. Osmania Uni., Hyderabad, India. p.152.

Eggum, B.O., and R.M. Beames. 1983. The nutritive value of seed proteins. pp. 499-531. In Seed Protein: Biochemisry, Genetics, and Nutritive Value. (eds. W. Gottschalk, and H.P. Muller), Martinus Nijhoff/W. Junk Publishers, The Hague, The Netherlands. 
Esh, G.C., T.S. De, and U.P. Basu. 1959. Influence of genetic strain and enviromment on the protein content of pulses. Science. 129:148.

Falvey, L., and T. Visitpanich. 1980. Nutrition of highland swine. 2. Preparation of pigeonpea seed fed in conjunction with rice bran and banana stalk. Thai J. Agrl. Sci. 13:29-34.

Faris, D.G., and U. Singh. 1990. Pigeonpea: Nutrition and Products. pp. 401-434. In The Pigeonpea (ed. Y.L. Nene, S.D. Hall, and V.K. Sheila), Wallingford, U.K. $\mathrm{CAB}$ Intemational.

Faris, D.G., K.B. Saxena, S. Mazumdar, and U. Singh. 1987. Vegetable pigeoupea: a promising crop for India. Patancheru, A.P., India: ICRISAT. p. 13.

Fuji, L., and L. Zhenghong. 1995. Research on feeding pigeonpea dry grains to pigs. Feed Industry. 7: 29-31.

Fuji, L., L. Zhenghong, Y. Jie, and C. Kunxian. 1995. Study on feeding pig by pigeonpea seed. Fodder Industry. 16 (7):29-31.

Geervani, P. 1981. Nutritional Evaluation of Pigeonpea (Variety Hyderabad 3A) processed by traditional methods. pp. 427-434. In Proc. Int. Workshop Pigeonpeas. Vol. 2, 15-19 December, 1980, ICRISAT, Patancheru, A.P. India.

Godbole, S.A., T.G. Krishna, and C.R. Bhatia. 1994. Changes in protease inhibitory activity from pigeonpea (Cajanus cajan (L.) Millsp.) during seed development and germination. J. Sci. Food and Agri. 66: 497-501.

Gridley, H.E., and A.M. Evans. 1979. Prospects of combining high yield with increased protein production in Phaseolus vulgaris L. pp. 47-58. In Proc. Symp. Seed Protein Impr. Cereals and Grain Legumes. Vol. II, IAEA, FAO and GSF. Neuherberg, Federal Republic of Germany.

Hamilton, T.S., B.C. Johnson, and H.H. Mitchell 1951. The dependence of the physical and chemical composition of the corn kernel on soil fertility and cropping system. Cereal Chem. 28:163-177.

Hartwig, E.E., and K. Hinson. 1972. Association between chemical composition of seed and yield of soybeans. Crop Sci. 12:829-830.

Henke, L.A., S.H. Work, and A.W. Burt. 1940. Beef cattle feeding trials in Hawaii. Hawaii Agrl. Exp. Sta. Bull. 85. Uni. Hawaii, Honolulu, Hawaii, USA.

Herrera, P.G., C.J. Lotero, and L.V. Crowder. 1966. Cutting frequency with tropical forage legumes. Agrl. Tropicale. 22: 473-483.

Hulse, J.H. 1977. Problems of nutritional quality of pigeonpea and chickpea and prospects of research. pp. 88-100. In Nutritional Standards and Methods of Evaluation for Food Legume Breeders. (eds. Hulse, J.H., K.O. Rachie, and L.W. Billingsley), Intl. Dev. Research Center, Ottawa, Canada.

ICRISAT. 1987. Annual Report 1986. Patancheru, A.P., India. ICRISAT. pp. 195-196. Imam, M.M. 1979. Variability in protein content of locally cultivated Phaseolus and Vigna spp. pp. 119-126. In Proc. Symp. Seed Protein Impr. Cereals and Grain Legumes. Vol. II, IAEA, FAO and GSF. Neuherberg, Federal Republic of Germany. Iyengar, A.K., and P.R. Kulkami. 1977. Oligosaccharide levels of processed legumes. J. Food. Sci. Tech. 14:222-223.

Jain, K.C., K.B. Saxena, U. Singh, L.J. Reddy, and D.G. Faris. 1986. Genotype environment interaction for protein content in pigeonpea. Int. Pigeonpea Newsletter. $5: 18-19$. 
Jambunathan, R., and U. Singh. 1981. Grain quality of pigeonpea. pp. 351-356. In Proc. Int. Workshop Pigeonpeas, Vol.1, 15-19 December 1980, ICRISAT, Patancheru, A.P., India.

Jyothi, E., and P.R. Reddy. 1981. The effect of germination and cooking on the in vitro digestibility of starch in some legumes. Nutr. Rep. Int. 23:799-804.

Kamath, M.V., and B. Belavady. 1980. Univailable carbohydrates of commonly consumed Indian foods. J. of Sci. of Food and Agric. 31, 194-202.

Krnuss, F.G. 1921. The pigeonpea (Cujanus indicus): its culture and utilization in $\mathrm{Ha}$ waii. Uni. of Hawaii Agril. Exp. Sta. Bull 46, Honolulu, Hawaii, USA.

Krauss, F.G. 1932. The pigeonpea (Cajanus indicus) its improvement, culture and utilization in Hawaii. Hawaii Agril. Exp. Sta. Bull. 64, Honolulu, Hawaii, USA.

Kumar, K.A., S.C. Gupta, and D.J. Andrews. 1983. Relationship between nutritional quality characters and grain yield in pearl millet. Crop Sci. 23:232-234.

Kurien, P.P. 1981. Advances in milling technology of pigeonpea, pp. 321-328. In Proc. Int. Workshop Pigeonpeas, Vol. 1, 15-19 December 1980, ICRISAT Center, Patancheru, A.P., India.

Kurien, S., D. Narayanaswamy, V.A. Daniel, M. Swaminathan, and H.A.B. Parpia. 1971. Supplementary value of pigeonpea (Cajanus cajan) and chickpea to poor diets based on kaffir corn and wheat. Nutri. Repts. Int. 4:227-232.

Manimekalai, G., S. Neelakantan, and R.S. Annapan. 1979. Chemical composition and cooking quality of some improved varieties of red gram dhal. Madras Agric. J. 66: 812-816.

Modi, J.D., and P.R. Kulkarni. 1976. Studies on starches of ragi and red gram. J. Food. Sci. Tech. 13 (1): 9-10.

Morton, J.F. 1976. The pigeonpea (Cajanus cajan (L.) Millsp.), a high protein tropical bush legume. Hort. Sci. 11(1): 11-19.

Mutimani, V.H., and S. Pwamjyothi. 1995. Protease inhibitors in some pigeonpea lines. Int. Chickpea and Pigeonpea Newsletter. 2:79-81.

Narasimha, H.V., and H.S.R. Desikachar. 1978. Objective methods for studying cookability of tur pulse (Cajanus cajan) and lactors affecting varietal differences in cooking. J. Food. Sci. Tech. 15:47-50.

Nigam, V.N., and K.V. Giri. 1961. Sugar in pulses. Can. J. Biochem. Physiol. 39: 1847-1853.

Nwokolo, E., and U.T. Oji. 1985. Variation in metabolizable energy of raw and autoclaved white and brown varieties of three tropical grain legumes. J. Animal Feed Sci. Tech. 13:141-146.

Oke, O.L. 1969. Sulphur nutrition of legumes, Expl. Agric. 5:111-116.

Pal, R.K. 1939. A review of the literature on the nutritive value of pulses. Ind. J. Agric. Sci. 9 (1):133-137.

Parbery, D.B. 1967. Pasture and fodder crop plant introductions at Kimberley Research Station, W. Australia 1963-1964. 1. Perennial Legumes. CSIRO Division of Land Research and Technology Memoir 6716. CSIRO, Melbourne, Australia.

Parpia, H.A.B. 1973. Utilization poblems in grain legumes.pp. 281-295. In Nutritional Impr. Food Legumes by Breeding. Protein Advisory Group, United Nations, New York. 
Pathak, G.N. 1970. Red gram. pp. 14-53. In Pulse Crops of India. Ind. Council of Agric. Research, New Delhi, India.

Pichare, M.M., and M.S. Kachole. 1994. Protease inhibitors of pigeonpea and its wild relatives. Int. Chickpea and Pigeonpea Newsletter. 1:44-46.

Pietri, R., R. Abrams, and F.J. Julie. 1971. Influence of fertility level on the protein content and agronomic characters of pigeonpea in an oxysol. J. Agric. Univ. Puerto Rico. 55(4): 474-477.

Prema, L., and P.A. Kurup. 1973. Hypolipidaemic activity of the protein isolated from Cajanus cajon in high fat-cholesterol diet fed rats. Ind. J. Biochem. Biophy. 10:293-296.

Rajalakshmi, R., and K. Vanaja. 1967. Chemical and biological evaluation of the effects of fermentation on the nutritive value of foods prepared from rice and legumes. British J. Nutr. 21:467-473.

Reddy, L.J., J.M. Green, U. Singh, S.S. Bisen, and R. Jambunathan. 1979. Seed protein studies on Cajanus cajan, Atylosia spp. and some hybrid derivatives. pp. 105-117. In Seed Protein Impr. Cereals and Grain Legumes, volume II. Intl. Atomic Energy Agency, Viemna.

Ryan, J.G. 1997. A global perspective on pigeonpea and chickpea sustainable production system: present status and future potential. pp. 1-32. In Recent Adv. in Pulses Res. (ed. A.N. Asthana and Masood Ali) Ind. Soc. Pulses Res. Dev. Ind. Inst. of Pulses Research, Kanpur, India.

Salunkhe, D.K. 1982. Legumes in human nutrition: current status and future research needs. Current Sci. 51:387-394.

Saxena, K.B., and D. Sharma. 1990. Pigeonpea genetics. pp. 137-157. In The Pigeonpea (ed. Y.L. Nene, S.D. Hall, and V.K. Shiela) CAB International, UK.

Saxena, K.B, S.J.B.A. Jayasekera, and H.P. Ariyarame. 1992. Pigeonpea varietal adaptation and production studies in Sri Lanka. ICRISAT, Patancheru. p. 173.

Saxena, K.B., U. Singh, and D.G. Faris. 1983. Does pod color affect the organoleptic qualities of vegetable pigeonpeas? Intl. Pigeonpea Newsletter. 2:74-75.

Saxena, K.B., R.V. Kumar, D.G. Faris, and L. Singh. 1987a. Breeding for special traits. Pigeonpea Breeding Annual Report, International Crops Research Institute for the Semi-Arid Tropics, Patancheru, A.P., India. p. 72.

Saxena, K.B., M.D. Gupta, and U. Singh. 1987b. Can seed size and protein content in pigeonpea be increased simultaneously? Int. Pigeonpea Newsletter. 6:29-31.

Saxena, K.B., D.G. Faris, U. Singh, and R.V. Kumar. 1987c. Relationship between seed size and protein content in newly developed high protein lines of pigeonpea. Plant Foods Hum. Nutr. 36: 335-340.

Saxena, K.B., D.G. Faris, and R.V. Kumar. 1984. Breeding for special traits. Pigeonpea Breeding Annual Report, International Crops Research Institute for the Semi-Arid Tropics, Patancheru, India. p. 99.

Sham, N.L. 1976. Effect of nitrogen, phosphorus and sulphur on protein content of arhar Cajanus cajan (L.). Seed Farming 2(5): 37-39.

Sharma, D., and K.B. Saxena. 1977. Relationship between seed size and yield in pigeonpea. Pigeonpea Breeding Annual Report, 1976-77. International Crops Research Institute for the Seni-Arid Tropics, Patancheru, India. p. 199. 
Sharma, Y.K., A.S. Tiwari, K.C. Rao, and A. Mishra. 1977. Studies on chemical constituents and their influence on cookability in pigeonpea. J. Food Sci. Tech. $14: 38-40$.

Shiying, Y., L. Yuxi, C. Chenbin, L. Shichun, and L. Hunchao. 1999. Observations on introduced pigeonpea. Guangxi Agric. Sci. 6: 309-310.

Singh, D.N., and A.K. Kush. 1981. Effect of population density on growth pattern and yielding ability in pigeonpea. pp. 165-174. In Proc. Int. Workshop Pigeonpeas, Vol. 1, 15-19 December 1980, ICRISAT Center, Patancheru, A.P., India.

Singh, L., and D. Sharma, and A.D. Deodhar. 1974. Effect of environment on protein content of seeds and implication in pulse improvement. pp. 731-808. In Proc. 2nd General Cong. SABRAO, New Delhi, India.

Singh, L., N. Singh, M.P. Shrivastava, and A.K. Gupta. 1977. Characteristics and utilization of vegetable types of pigeonpeas (Cajanus cajan (L.) Millsp.). Ind. J. Nutri. Diet. $14: 8-10$

Singh, U. 1984. The inhibition of digestive enzymes by polyphenols of chickpea (Cicer arietinum L.) and pigeonpea (Cajanus cajan (L.) Millsp.). Nutr. Rep. Int. 29:745-753.

Singh, U. 1988. Antinutritional factors of chickpea and pigeonpea and their removal by processing. Pl. Foods Human Nutri. 38, 251-261.

Singh, U., and B.O. Eggum. 1984. Factors affecting the protein quality of pigeonpea (Cajanus cajan L.). Qual. Plant. Plant Foods Human Nutr. 34:273-283.

Singh, U., and R Jambunathan. 1990. Pigeonpea: post-harvest technology. pp. 435-455. In The Pigeonpea (ed. Y.L. Nene, S.D. Hall and V.K. Sheila), Wallingford, UK. $\mathrm{CAB}$ International.

Singh, U., and R. Jambunathan. 1981. A survey of the methods of milling and consumer acceptance of pigeonpeas in India. pp. 419-425. In Proc. Intl. Workshop Pigeonpeas, Vol. 2:15-19 December 1980. ICRISAT, Patancheru, A.P. India.

Singh, U., and R. Jambunathan. 1982. Distribution of seed protein fractions and amino acids in different anatomical parts of chickpea (Cicer arietimum L.) and pigeonpea (Cajanus cajan L.). Qual. Plant. Plant Foods Human Nutr. 31: 347-354.

Singh, U., K.C. Jain, R. Jambunathan, and D.G. Faris. 1984a. Nutritional quality of vegetable pigeonpeas [Cajanus cajan (L.) Millsp.]: dry matter accumulation, carbohydrates and proteins. J. Food Sci. 49:799-802.

Singh, U., K.C. Jain, R. Jambunathan, and D.G. Faris. 1984b. Nutritional quality of vegetable pigeonpeas [Cajanus cajan (L.) Millsp.]: mineral and trace elements. J. Food Sci. 49:645-646.

Singh, U., M.S. Khardekar, and K.C. Jain. 1984c. Effect of growing season on the cooking quality of pigeonpea. Int. Pigeonpea Newsletter 3:50-51.

Singh, U., P. Venkateshwara Rao, K.B. Saxena, and L. Singh. 1991. Chemical changes at different stages of seed development in vegetable pigeonpeas (Cajanus cajan). J. Sci. Food Agric. 57:49-54.

Singh, U., R. Jambunathan, K.B. Saxena, and N. Subramaniam. 1990. Nutritional quality evaluation of newly developed high protein genotypes of pigeonpea [Cajanus cajan L.) J. Sci. Food Agric. 50:201-209.

Springhall, J., J.O. Akinola, and P.C. Whiteman 1974. Evaluation of pigeonpea (Cajanus cajon) seed meal in chicken rations. pp. 117-119. In Proc., Austr. Poultry Sci. Convention, Sydney, Australia. 
Squire, F.A. 1933. Guiva Department of Agriculture, Rice Bull. No. 1: 51-57.

Srivastava, S., D.P. Mishra, and B.P. Khare. 1988. Effect on insect infestation on biochemical composition of pigeonpea (Cajanus cajan (L) Millsp.) seeds stored in mud bin. Bull. Grain Tech. 26: 120-125.

Swaminathan, M.S. 1973. Basic research for further improvement of pulse crops in South East Asia. pp. 61-68. In Nutritional improvement of food legumes by breeding (ed. M.M. Milner). Protein Advisory Group, United Nations.

Tripathi, R.D., G.P. Srivastava, M.C. Misra, and S.C. Sinha. 1975. Comparative studies in the quality characteristics of early and late cultivars of red gram (Cajanus cajan L.). Ind. J. Agric. Chem. 8: 57-61.

Uma Reddy, M., and P. Pushpamma. 1981. Effect of insect infestation and storage on the nutritional quality of different varieties of pigeonpea. pp. 443-451. In Proc. Int. Workshop Pigeonpeas, Vol. 2:15-19 December 1980. ICRISAT, Patancheru, A.P. India.

Vimala, V., and P. Pushpamma. 1983. Storage quality of pulses stored in three agro-climatic regions of Andhra Pradesh-1-Quantitative changes. Bull. Grain Tech. $21: 54-62$.

Vimala, V., and P. Pushpamma. 1985. Effect of improved storage methods on cookability of pulses stored for one year in different containers. J. Food Sci. Tech. 22:327-329.

Wallis, E.S., D.G. Faris, R. Elliott, and D.E. Byth. 1986. Varietal improvement of pigeonpea for smallholder livestock production systems. pp. 536-553. In Proc. of the Crop-livestock Systems Research Workshop, 7-11 July 1986, Khon Kaen, Thailand. Farming Systems Research Institute, Department of Agriculture, Thailand and Asian Rice Farming Systems Network, International Rice Research Institute, Philippines.

Wayne, J.C., and A.J. Casady. 1974. Heritability and interrelationship of grain protein content with other agronomic traits in sorghum. Crop Sci. 14:622-624.

Whiteman, P.C., and B.W. Norton. 1981. Alternative uses of pigeonpeas. pp. 365-377. In Proc. Intl. Workshop Pigeonpeas, Vol. 1, 15-19 December 1980, ICRISAT Center, India. Patancheru, A.P., India.

Work, S.H. 1946. Digestible nutrient content of some Hawaiian feeds and forages. Uni. Hawaii. Agril. Exp. Stn. Tech. Bull. 4, Honolulu, Hawaii, USA.

Yadav, S.P. 1984. Physical and chemical analyses of pigeonpea (Cajanus cajan) cultivar and $F_{1}$ crosses. J. Sci. Food Agric. 35:833-836. 